\title{
Reflections on Local Community Identity by Evaluating Heritage Sustainability Protection in Jugra, Selangor, Malaysia
}

\author{
Zainab Binti Roslan ${ }^{1}$, Zuliskandar Ramli ${ }^{1, *}$, Muhammad Rizal Razman ${ }^{2}{ }^{\circledR}$, M. R. M. Asyraf $\left.{ }^{3}{ }^{(}\right)$, M. R. Ishak ${ }^{3}$, \\ R. A. Ilyas ${ }^{4,5}$ (i) and N. M. Nurazzi ${ }^{6}(\mathbb{D}$
}

1 Institute of the Malay World and Civilisation (ATMA), Universiti Kebangsaan Malaysia (UKM), Bangi 43600, Selangor, Malaysia; zaynabroslan@gmail.com

2 Research Centre for Sustainability Science and Governance (SGK), Institute for Environment and Development (LESTARI), Universiti Kebangsaan Malaysia (UKM), Bangi 43600, Selangor, Malaysia; mrizal@ukm.edu.my

3 Department of Aerospace Engineering, Faculty of Engineering, Universiti Putra Malaysia (UPM), Seri Kembangan 43400, Serdang, Malaysia; asyrafriz96@gmail.com (M.R.M.A.); mohdridzwan@upm.edu.my (M.R.I.)

4 Sustainable Waste Management Research Group (SWAM), School of Chemical and Energy Engineering, Faculty of Engineering, Universiti Teknologi Malaysia, Johor Bahru 81310, Johor, Malaysia; ahmadilyas@utm.my

5 Centre for Advanced Composite Materials, Universiti Teknologi Malaysia, Johor Bahru 81310, Johor, Malaysia

6 Centre for Defence Foundation Studies, Universiti Pertahanan Nasional Malaysia (UPNM), Kem Perdana Sungai Besi, Kuala Lumpur 57000, Malaysia; mohd.nurazzi@gmail.com

check for updates

Citation: Roslan, Z.B.; Ramli, Z.; Razman, M.R.; Asyraf, M.R.M.; Ishak, M.R.; Ilyas, R.A.; Nurazzi, N.M. Reflections on Local Community Identity by Evaluating Heritage Sustainability Protection in Jugra, Selangor, Malaysia. Sustainability 2021, 13, 8705. https://doi.org/ $10.3390 /$ su13168705

Academic Editors: Lucia Marchegiani and Enrico Cori

Received: 5 July 2021

Accepted: 29 July 2021

Published: 4 August 2021

Publisher's Note: MDPI stays neutral with regard to jurisdictional claims in published maps and institutional affiliations.

Copyright: (C) 2021 by the authors. Licensee MDPI, Basel, Switzerland. This article is an open access article distributed under the terms and conditions of the Creative Commons Attribution (CC BY) license (https:/ / creativecommons.org/licenses/by/ $4.0 /)$.
* Correspondence: ziskandar@ukm.edu.my

\begin{abstract}
The purpose of this study is to evaluate the value derived by the local community from cultural heritage and natural heritage in Jugra, Kuala Langat, as it has the potential to be a recognized heritage tourism site. The quantitative approach was used by conducting a survey study. A total of 392 respondents among the local community were selected through a purposive sampling technique. The collected data were processed with SPSS software and analyzed using cross tabulation analysis. Then, several hypotheses were tested using AMOS software. The result showed that Jugra's unique heritage elements positively influenced the respondent's willingness to accept and fund its tourism development. Socioeconomic factors also influenced the respondents' disposition to preserve heritage. The findings revealed that there was priceless value when respondents agreed with the development, although they had never visited the heritage sites. Their physical, economic, and social valuation made them proud of the heritage, as it is a reflection of their identity. This study also aims to emphasize the role of local community as one of the stakeholders, as they should also be able to benefit from tourism development. All these would help boost the tourism industry, particularly through the archaeo-tourism and eco-tourism perspectives.
\end{abstract}

Keywords: cultural heritage; natural heritage; heritage tourism; identity; sustainability; willingness to pay; Jugra

\section{Introduction}

The United Nations of World Tourism Organization (UNWTO) [1] and Zyl [2] define tourism as temporary travel by a person not exceeding a year, outside of his usual destinations without any remuneration from the workplace or residence. Maneenetr [3] (2008) described tourism as the social, economic, and political interactions between organizations, communities, visitors, and products. Tourism development has gotten worldwide recognition as an impetus for economic growth, agriculture, and energy development and poverty alleviation [4-10]. The Association of Southeast Asian Nations, or ASEAN [11], defines tangible heritage as cultural heritage, including the structures, artefacts, and sites, whereas oral, folk, and popular cultural heritage, including fashion and costumes and 
human habits, are considered intangible cultural heritage (ICH) [12-16]. Similarly, heritage tourism also refers to the physical development by the modernization of social structures to meet tourists' expectations in history, art, culture, nature, etc. Meanwhile, heritage tourism development relates to the sustainable tourism that will lead to the maintenance of cultural integrity, social network, physical environment, and protecting biodiversity, which serve as the cultural, social, and economic resources [3,17-19]. According to Ramli [20], heritage tourism can be categorized into cultural heritage (tangible and intangible heritage) and natural heritage. In addition, he stated that the conservation and preservation of heritage assets are significant, particularly when used as means of archaeo-tourism [21-26] and ecotourism [27-29]. Navrud and Ready [30] stated that heritage assets could be analyzed by conservationists through the economic valuation method. The valuation process would create heritage values that can be defined as the benefits gained by the users who are willing to pay for the protection of those assets. The willingness of people to pay is one of the most important theories used to reflect heritage values given by individuals in a community [30-32]. Throsby et al. found a significant contribution by the four dimensions of cultural value-aesthetic value, historical value, social value, and architectural value- to the formation of conservation preferences and through the public's willingness to pay [33]. Heritage education is essential in order to create all these cultural values merely among the younger generations. The implementation of heritage education programs, for example, by using new technologies achieved an impact on the community. This program enables pupils to identify and value their heritage, and thereby contribute to the safeguarding of the local heritage [34].

Gizzi et al. [35] recognized the cultural heritage significance attributed to the identity of the heritage that belong to the communities, to reunite communities with places and objects that belong to them, to return the value of the relationship between the site and its surroundings, to informally learn about the object and its symbolic meaning that characterizes it within the history of that community, and to identify the methods and tools capable of repairing that link between the individual and the social value of the cultural good. These would help an individual from a community to be active and proactive in preserving the cultural heritage for posterity [35-38].

According to Muganda et al. [39], one of the core elements in sustainable tourism development is to encourage the participation of the local community. The local community should be an integral part of the current decision-making process at both the planning and management levels [40-43], and thus their involvement cannot be neglected [44-46]. The involvement of the local community in the decision-making process pertaining to development issues is crucial to ensure that planned development policies are always in the best interests of the community and meet their needs in line with the physical, economic, and social development impacts [39,44]. Mohd Din [47] also pointed out that the involvement of the local community can certainly be helpful not just in the form of funding, but also in promoting and supporting the development efforts of heritage sites, particularly in the study area. The awareness of the local community of the importance of heritage conservation is also vital in educating future generations in understanding and appreciating history. It also can provide the opportunity to experience and enjoy the benefits reaped from heritage tourism. Additionally, it emphasizes environmental well-being by increasing heritage conservation awareness, mainly amongst the local community, as heritage assets reflect the identity of their origins $[3,48]$. Target 11.4 of Sustainable Development Goal 11 (SDG 11) aims to "strengthen efforts to protect and safeguard the world's cultural heritage and natural heritage" [15,49-51]. Therefore, the local communities' evaluation of heritage protection needs to be identified in order to put emphasis on the significance of heritage asset preservation in the area, so that proper planning for its long-term protection can be implemented. This study also aims to emphasize the role of the local community as one of the stakeholders, as they should also be able to benefit from tourism development. The study also used a semiotics approach, which has been used effectively in tourism-related studies over the last two decades. 


\section{Materials and Methods}

\subsection{Study Area}

Jugra is said to have existed for 2500 years, and historians believe that Langat was once its original site. Researchers have discovered artefacts from a series of excavations in 1964 at Kampung Sungai Lang [52]. The locations of Jugra sub-district and Kuala Langat district are shown in Figure 1. From a linguistic point of view, researchers have stated that the Jugra dialect indeed represents the ancient Selangor dialect, which was previously thought to be non-existent [53]. Jugra also became well known as a transit area during the Malacca Sultanate era, based on its terrains and strategic location, which are situated along the coast and river mouth [54-56]. Moreover, in 18th century, Jugra was once the administrative center of Selangor when the fourth Sultan of Selangor, Al Marhum Sultan Abdul Samad Ibni Sultan Abdullah (SASSA), resided there (1875-1898). SASSA built several palaces and resided there in 1875. Therefore, Jugra was established as the development hub of social, economic, and political life in Selangor. During the reign of SASSA, Jugra witnessed various historical events, such as the civil wars of Klang I and Klang II (1866-1874) that affected British colonialism in Malaysia. After the demise of SASSA, his grandson, Sultan Ala'uddin Suleiman Shah Ibni Raja Musa (SASRM), became the fifth Sultan of Selangor. SASRM resided in Jugra for 35 years and brought about many physical, economic, and social developments to the state before he moved and passed away in Klang [57-60]. Accordingly, the remains of its historic evidence still exist as cultural heritage that bears aesthetic value and unique designs. The population in Jugra is estimated to be about 8582 out of more than 200,000 people in Kuala Langat, Selangor. Most of the people in Jugra work as farmers, fishermen, entrepreneurs, construction workers, civil servants, or in private companies, the banking sector, or utilities sector, [61]. Fortunately, Jugra also has natural heritage assets that are rich in biodiversity and serve as the habitat for natural resources. All these assets need to be preserved for future generations, as they have significant historic, spiritual, and scientific value from previous civilizations that is irreplaceable. Unfortunately, previous research found that heritage assets in the study area were recorded and categorized, but these treasures were not systematically managed. One of the key challenges in management systems is the lack of cooperation and attitudinal attentions by stakeholders such as local authorities, non-governmental organizations (NGOs), or the local community themselves, especially the owners of the inheritance. The study also discussed the financial aspects of managing heritage assets so that good management systems can be implemented. The integration part of planning, management, engagement, and cooperation among stakeholders should be strengthened to ensure consistent development in line with the legal system and conservation guidelines as provided by the government [52]. Table 1 and Figures 2 and 3 include the lists of cultural heritage and natural heritage elements in Jugra that have been identified.

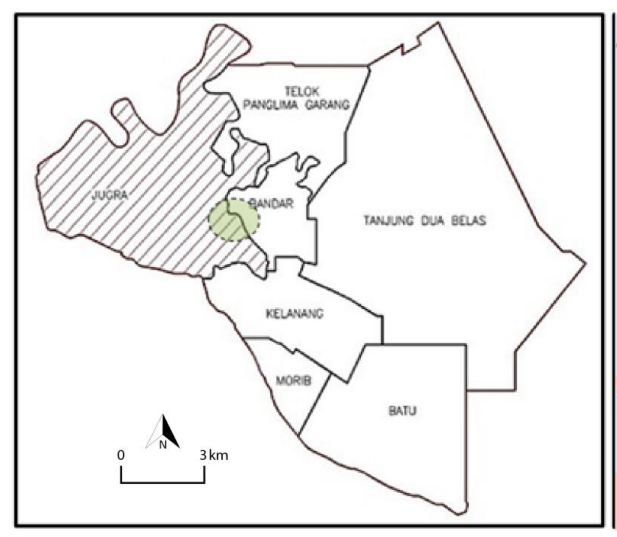

(a)

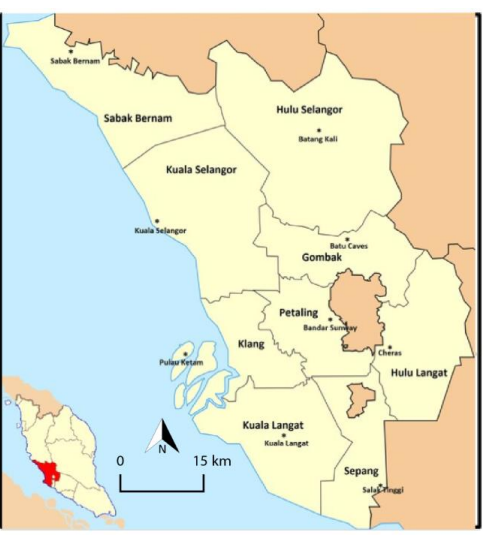

(b)

Figure 1. Map of the study area of (a) Jugra in (b) Kuala Langat district in Selangor state. 
Table 1. Cultural and natural heritage elements in Jugra [60].

\begin{tabular}{llll}
\hline \multicolumn{1}{c}{ Cultural Heritage } & \multicolumn{1}{c}{ Natural Heritage } \\
\hline 1. & Archaeological site & 1. & Jugra Reserved Forest \\
2. & Long Puteri Palace & 2. & Langat River \\
3. & Royal Mausoleum of Al Marhum Sultan Abdul Samad & 3. & Mangrove Forest \\
4. & The Ammunition Dump & 4. & Physical terrain-mountain \\
5. & The Old Kuala Langat District Office & & \\
6. & The Old Jugra Prison & & \\
7. & Bandar Palace & & \\
8. & Alaeddin Mosque & & \\
9. & The Bandar National School Batu Hampar Jetty & \\
10. $\quad$ Jugra Lighthouse &
\end{tabular}

Jugra Palace ruins

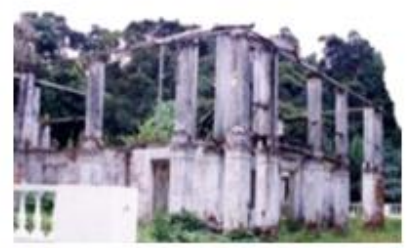

In 1876- Sultan Abdul built an official residence for him to reside.

Tomb of Al Marhum Sultan Abdul Samad

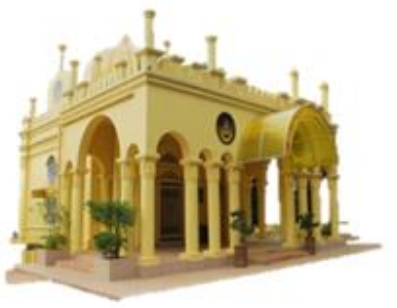

In 1898, Al Marhum Sultan Abdul Samad Ibni Tengku Abdullah died and was buried on one of the hills in Jugra.

The Old Kuala Langat District Office ruins

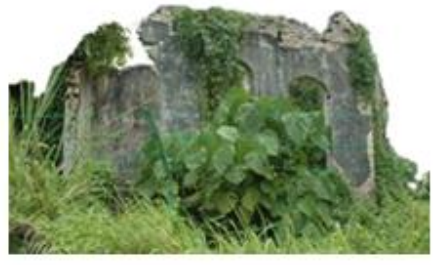

1876- The administrative office of the British government system. Placed the British Resident's assistant, Frank Swettenham.
Long Puteri Palace ruins

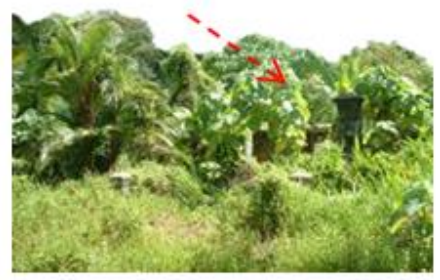

In 1890- Sultan Abdul Samad built a Palace for his granddaughter named Raja Long.

The Ammunition Dump

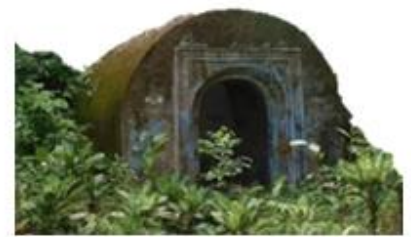

In 1876, The Ammunition Dump Stor built by British

Old Jugra Prison

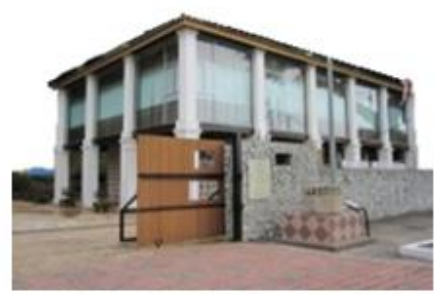

1875- The prison was built by British. It used to serve as a police office and prison. It has now been preserved into the Insitu Museum.

Figure 2. Old Building/monument associated with Sultan Abdul Samad's reign that still exists today. 


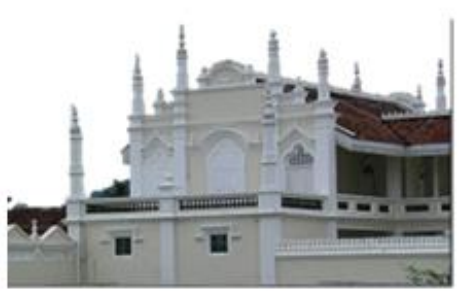

In 1898 , Istana Bandar was built during Sultan Ala'uddin Sulaiman Shah reign

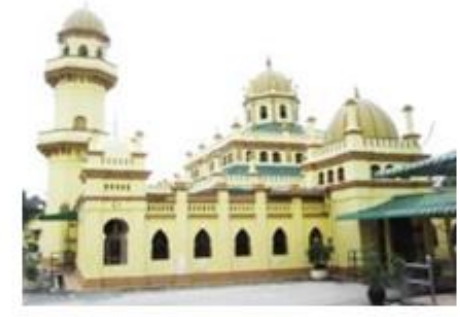

In 190, Alaeddin Mosque was built during Sultan Ala'uddin Sulaiman Shah reign.

\section{The Bandar National School}

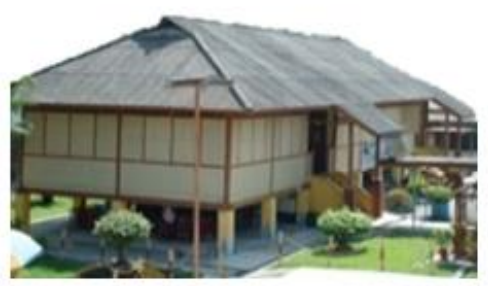

In 1898 , originally function as a mosque during Sultan Ala'uddin Sulaiman Shah reign and still used untill today as a Islamic school.

Figure 3. Old building/monument associated with Sultan Ala'uddin Sulaiman Shah's reign that still exists today.

\subsection{Semiotics of the Study}

Semiotics refers to the science of signs or any system that is related to the use of symbol or marks [62]. In the 19th century, Charles Sanders Pierce (1839-1914), a philosopher from the United States who authored the Collected Papers (reconstituted in 1931 by Charles Harthstorne, Paul Wiess, and Arthur W. Burks), stated that semiotics has links to logical character, which can connect the relationship between signifier (marker) and signified through the symbol of a sign. It can be considered arbitrary by the three components, which are icons, symbols, and indexes [62,63]. Semiotics has been used effectively in tourism-related studies over the last two decades [64,65]. According to MacCannell [63], he adapted semiotics in tourism as written in a book titled The Tourist. MacCannell used the Pierce approach, which uses the beauty and uniqueness of a tourist destination as a means to influence a visitor's motivation to visit the site. An example given by MacCannell is the Eiffel Tower, which became a major tourist attraction in Paris, and the Empire State building is the main tourist attraction in Manhattan. These buildings were built to be a sign that symbolizes the identity of the place they are located in $[64,66]$. In addition, this study adapted Piercean semiotics by using the Piercean triadic model of signs to form a conceptual framework for the study. The cultural heritage and natural heritage elements in the study area were used to symbolize local identity by evaluating the locals' interpretation of the heritage protection. As illustrated in Figure 4, the semiotic process occurs via three components-the first component is the signifier (representing the uniqueness of the heritage elements in Jugra) to interpret the second component of the local community (signified). Hence, the locals' evaluation and interpretation on the signifier represents the attractiveness towards heritage tourism development, which is the third component. The 
interchangeability between the signified and the signifier through heritage evaluation acts as a link to form the continuation in a triangular relationship. Generally, this process will create heritage values that are influenced by the local community perceptions, experiences, and level of awareness towards the importance of heritage protection. These heritage values represent the dependent variables in the study. The involvement of the local community signifies both direct and indirect used values. Direct used value refers to the people who get the benefits of the heritage protection directly because they use the heritage site as a place of residence, workplace, recreation area, or trip destination, whereas indirect used value represents the people who have no visiting experience at the heritage site but get the benefits indirectly because they live in the area. There is an intrinsic value when they have never visited the heritage site, but they have an internal awareness of protecting the site so that the treasures can be enjoyed by other users. The goal of the implementation is to conserve the heritage assets (altruistic value) and decide to make the site become a recognizable heritage tourism destination for future use and biodiversity well-being (option value). There is a bequest value when preserving the uniqueness of the heritage site that can be inherited by future generations. All these dependent variables may influence the socioeconomic factors such as education, occupation, and income that can affect users' disposition and consent towards heritage tourism development efforts [30,67].

(Signifier) - Cultural and natural heritage elements

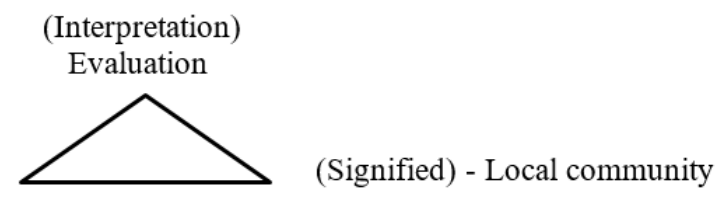

Figure 4. Pierce's triadic model of signs adapted in this study.

\subsection{Methodology}

A quantitative survey was conducted over eight weeks from 6 November to 28 December 2015 to evaluate the values derived by the local community towards the cultural heritage and natural heritage in the study area. The purposive sampling technique was chosen and applied to the target population of the local people in Kuala Langat, who have been living in the area for over three years. Figure 5 indicates the values created by the locals through the survey.

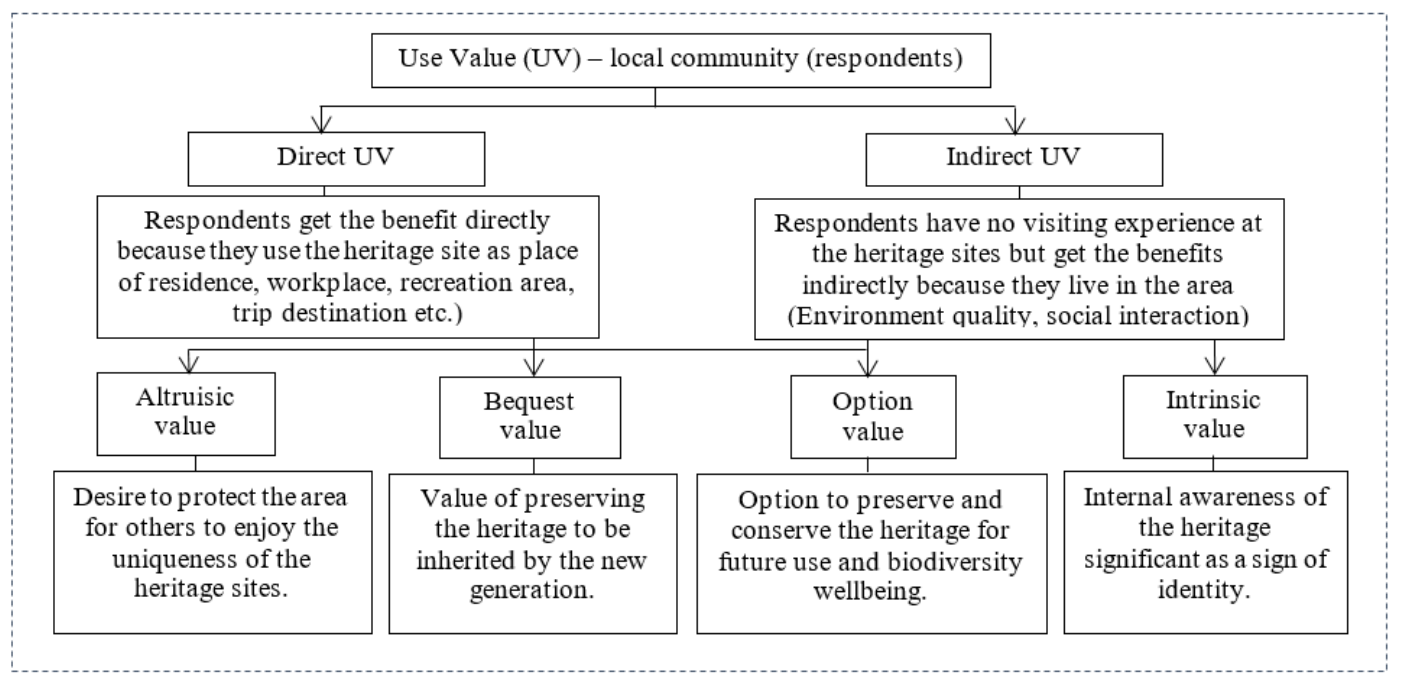

Figure 5. Illustration of the values derived by the locals from the survey.

Based on the pilot survey, despite the fact that all respondents have lived in the area for more than three years, some still did not recognize the heritage elements and had never visited the area. Therefore, in the major survey with a total of 392 respondents (from 
the 400 respondents who returned with positive feedback), the distribution technique used was the face-to-face technique. The technique also included displays of pictorial or visual information about the heritage elements. This technique can attain 80 percent or more effectiveness and fast response from the respondents compared to other methods such as online survey, electronic media, or mail [68]. The questionnaire had 36 total questions, consisting of two types of close-ended questions. Firstly, the five-point Likert scale questions were used to estimate the respondents' perception of or disposition towards heritage protection in the study area, and secondly, dichotomous questions were used to ask the respondents to answer either "Yes" or "No." This type of question was used to identify the respondents' willingness to pay for heritage protection, options to choose the uniqueness of heritage elements in the study area, and then to find out whether the respondents had or had not visited the study area [59]. The data were processed using IBM SPSS Statistics version 21. Basic descriptive analyses of percentages and frequencies were applied to attain the respondents' demographic data and to calculate the total number of respondents who accepted heritage tourism development and were willing to contribute to its funding. Then, inferential analyses were also applied, namely, cross-tabulation analyses by using the Chi-square test in SPSS software to study the correlation between variables, as depicted below:

1. Cross-tabulation between respondents' acceptance of heritage tourism development in the study area and their visiting experience at the heritage sites.

2. Cross-tabulation between respondents' willingness to pay (WTP) for the heritage conservation and their acceptance of tourism development in study area.

In addition, the study also applied structural equation modelling (SEM) using regression and moderation tests in AMOS software to test the hypotheses as listed below:

Hypothesis $\mathbf{1}\left(\mathbf{H}_{\mathbf{1}}\right)$. There is a significant statistical correlation between the uniqueness of heritage elements in Jugra and respondents' willingness to pay for heritage conservation and tourism development purposes.

Hypothesis $\mathbf{2}\left(\mathbf{H}_{\mathbf{2}} \mathbf{)}\right.$. There is a significant statistical correlation between the uniqueness heritage elements in Jugra and respondents' consent to heritage tourism development.

Hypothesis $\mathbf{3}\left(\mathbf{H}_{3}\right)$. Socioeconomic factors act as a moderator between respondents' dispositions towards heritage preservation and their acceptance of tourism development in the study area.

\section{Results}

Based on the analysis of the demographic data of 392 respondents, there was a slight difference by gender, the number of male and female respondents, of $4 \%$. In terms of age, the survey consisted of the highest total of number respondents as between 16 and 34 years old $(61.0 \%)$, followed by $20.9 \%$ of respondents aged between 35 and 44 years old. In terms of educational background, the majority of the respondents had completed secondary school, whereas only $7.2 \%$ of them had no formal education or had only completed primary education. In terms of occupation, the highest number of respondents (31.4\%) was comprised of technicians or officers. Then, by monthly gross income, the majority of the respondents earned no more than RM 900 monthly (29.3\%). Most of the respondents had visited the heritage area (77.3\%). Less than half of the total respondents were willing to pay for heritage tourism development (46.7\%). Nevertheless, the majority of them accepted the study area as a choice heritage tourism site (96.9\%). A summary of the respondents' demographic data is indicated in Table 2. 
Table 2. Summary of the respondents' demographic data [60].

\begin{tabular}{|c|c|c|c|}
\hline \multicolumn{2}{|c|}{ Demographic Variables } & \multirow[t]{2}{*}{ Frequency } & \multirow[t]{2}{*}{ Percentage $(\%)$} \\
\hline Gender & & & \\
\hline- & Male & 203 & 52 \\
\hline- & Female & 189 & 48 \\
\hline & Total & 392 & 100 \\
\hline \multicolumn{4}{|l|}{ Age } \\
\hline- & $16-24$ & 119 & 30.4 \\
\hline- & $25-34$ & 120 & 30.6 \\
\hline- & $35-44$ & 82 & 20.9 \\
\hline- & $45-54$ & 47 & 12 \\
\hline- & $55-64$ & 15 & 3.8 \\
\hline- & $>65$ & 9 & 2.3 \\
\hline & Total & 392 & 100 \\
\hline \multicolumn{4}{|c|}{ Education level } \\
\hline- & No formal education & 4 & 1.3 \\
\hline- & Primary school & 23 & 5.9 \\
\hline- & Secondary school & 222 & 56.6 \\
\hline- & Diploma & 96 & 24.5 \\
\hline- & First degree & 42 & 10.5 \\
\hline- & Masters/PhD & 5 & 1.3 \\
\hline & Total & 392 & 100 \\
\hline \multicolumn{4}{|c|}{ Occupation } \\
\hline- & Professional/Managerial & 58 & 14.8 \\
\hline- & Technician/Officer & 123 & 31.4 \\
\hline- & Freelance/Own business & 110 & 28.1 \\
\hline- & Student & 70 & 17.9 \\
\hline - & Not & 31 & 7.9 \\
\hline working & lousewife/Retired & 392 & 100 \\
\hline \multicolumn{4}{|c|}{ Monthly gross income } \\
\hline- & $<$ RM 900 & 115 & 29.3 \\
\hline- & RM 901-RM 1500 & 102 & 26.0 \\
\hline- & RM 1501-RM 2000 & 54 & 13.8 \\
\hline- & RM 2001-RM 3000 & 58 & 14.8 \\
\hline- & RM 3001-RM 4000 & 37 & 9.4 \\
\hline- & RM 4001-RM 5000 & 15 & 3.8 \\
\hline- & RM 5001-RM 6000 & 5 & 1.3 \\
\hline- & $>$ RM 6001 & 6 & 1.5 \\
\hline & Total & 392 & 100 \\
\hline \multicolumn{4}{|c|}{ Have visited the heritage area } \\
\hline- & Yes & 303 & 77.3 \\
\hline- & No & 89 & 22.7 \\
\hline & Total & 392 & 100 \\
\hline \multicolumn{4}{|c|}{ Willingness to pay (WTP) } \\
\hline - & WTP & 183 & 46.7 \\
\hline- & Not WTP & 209 & 53.3 \\
\hline & Total & 392 & 100 \\
\hline \multicolumn{4}{|c|}{$\begin{array}{l}\text { Acceptance of Jugra as a heritage tourism } \\
\text { site }\end{array}$} \\
\hline- & Yes & 379 & 96.9 \\
\hline- & No & 13 & 3.1 \\
\hline Total & & 392 & 100 \\
\hline
\end{tabular}

\subsection{Cross Analysis}

3.1.1. Cross Tabulation between Respondents' Acceptance of Heritage Tourism Development in Jugra and Their Visiting Experience at the Heritage Sites

According to Seok et al. [69] and Garczynski [70], the significant value (alpha value) for the Pearson chi square should be less than $(<)$ 0.05. As shown in Table 3 , the $X^{2}$ value at continuity correction (must refer if any) was 0.000 at an asymptotic significant level 
(alpha value) of 1.000. As the significant value exceeded 0.05, it shows that the respondents' acceptance of the heritage tourism development in the study area was not correlated with their visiting experience at the heritage sites $\left(X^{2}=0.000, d f=1, k>0.05\right)$.

Table 3. Chi-square test results for correlation between the respondents' acceptance of Jugra as a heritage tourism site and visiting experience at the heritage sites.

\begin{tabular}{|c|c|c|c|c|c|}
\hline Parameter & $\begin{array}{l}\text { Value } \\
\left(X^{2}\right)\end{array}$ & $\mathrm{df}$ & $\begin{array}{l}\text { Asymptotic Sig. } \\
\text { (2-Sided) }\end{array}$ & $\begin{array}{l}\text { Exact Sig. } \\
\text { (2-Sided) }\end{array}$ & $\begin{array}{l}\text { Exact Sig. } \\
\text { (1-Sided) }\end{array}$ \\
\hline Pearson Chi-Square & $0.001^{\mathrm{a}}$ & 1 & 0.974 & & \\
\hline Continuity Correction $\mathrm{b}$ & 0.000 & 1 & 1.000 & & \\
\hline Likelihood Ratio & 0.001 & 1 & 0.974 & & \\
\hline Fisher's Exact Test & & & & 1.000 & 0.597 \\
\hline $\begin{array}{l}\text { Linear-by-Linear } \\
\text { Association }\end{array}$ & 0.001 & 1 & 0.974 & & \\
\hline $\mathrm{N}$ of Valid Cases & 392 & & & & \\
\hline
\end{tabular}

a. 1 cell $(25.0 \%)$ has an expected count of less than 5 . The minimum expected count is $2.95{ }^{\mathrm{b}}$. Computed only for a $2 \times 2$ table.

Furthermore, Table 4 and Figure 6 illustrate that 22.7\% (86 frequencies) of respondents had never visited the heritage sites but accepted heritage tourism development in the study area. Thus, the study found that there was an intrinsic value among respondents who were aware on the importance of the preservation and conservation of heritage elements, despite having never seen the treasures. Nonetheless, they still wanted to protect it for the benefit of others and future generations (bequest value-refer to the explanation in the subtopic of "semiotics" in the study).

Table 4. Cross-tabulation between acceptance of Jugra as a heritage tourism site and visiting experience at the heritage sites.

\begin{tabular}{|c|c|c|c|c|c|}
\hline & & & \multicolumn{2}{|c|}{$\begin{array}{l}\text { Acceptance of Jugra as a } \\
\text { Heritage Tourism Site }\end{array}$} & \multirow[t]{2}{*}{ Total } \\
\hline & & & Yes & No & \\
\hline \multirow{9}{*}{$\begin{array}{l}\text { Have visited the } \\
\text { heritage area }\end{array}$} & \multirow{5}{*}{ Yes } & Count & 293 & 10 & 303 \\
\hline & & Expected Count & 293.0 & 10.0 & 303.0 \\
\hline & & $\%$ have visited the heritage area & $96.7 \%$ & $3.3 \%$ & $100.0 \%$ \\
\hline & & $\begin{array}{c}\% \text { acceptance of Jugra as a heritage } \\
\text { tourism site }\end{array}$ & $77.3 \%$ & $76.9 \%$ & $77.3 \%$ \\
\hline & & $\%$ total & $74.7 \%$ & $2.6 \%$ & $77.3 \%$ \\
\hline & \multirow{10}{*}{ No } & Count & 86 & 3 & 89 \\
\hline & & Expected Count & 86.0 & 3.0 & 89.0 \\
\hline & & $\%$ have visited the heritage area & $96.6 \%$ & $3.4 \%$ & $100.0 \%$ \\
\hline & & $\begin{array}{c}\% \text { acceptance of Jugra as a heritage } \\
\text { tourism site }\end{array}$ & $22.7 \%$ & $23.1 \%$ & $22.7 \%$ \\
\hline \multirow{6}{*}{ Total } & & $\%$ total & $21.9 \%$ & $0.8 \%$ & $22.7 \%$ \\
\hline & & Count & 379 & 13 & 392 \\
\hline & & Expected Count & 379.0 & 13.0 & 392.0 \\
\hline & & $\%$ have visited the heritage area & $96.7 \%$ & $3.3 \%$ & $100.0 \%$ \\
\hline & & $\begin{array}{c}\% \text { acceptance of Jugra as a heritage } \\
\text { tourism site }\end{array}$ & $100.0 \%$ & $100.0 \%$ & $100.0 \%$ \\
\hline & & $\%$ total & $96.7 \%$ & $3.3 \%$ & $100.0 \%$ \\
\hline
\end{tabular}




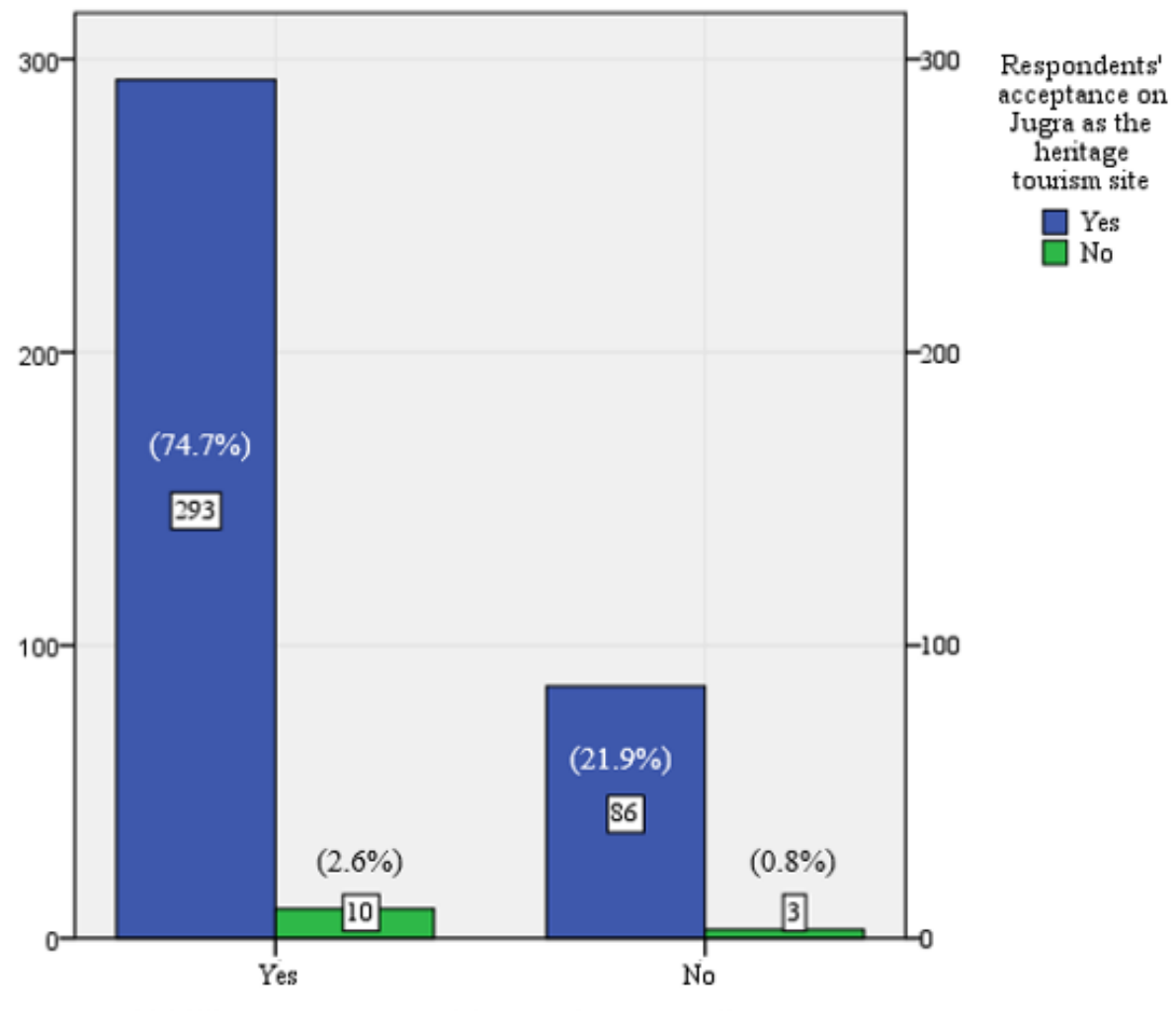

Visiting experience at the heritage area in Jugra

Figure 6. Bar chart of respondents' acceptance of Jugra as a heritage tourism site and their visiting experience at the heritage area in Jugra.

3.1.2. Cross-Tabulation between Respondents' Willingness to Pay (WTP) for Heritage Conservation and Their Acceptance of Tourism Development in Jugra

As illustrated in Table 5, the Pearson chi-square value $X^{2}$ at continuity correction is 0.103 , and at asymptotic significance, the alpha value is 0.748 . The alpha value exceeded 0.05. Thus, the result showed that the correlation between respondents' willingness to pay (WTP) for heritage conservation and their acceptance of tourism development in the study area was not significant $\left(X^{2}=16.975, \mathrm{df}=1, \mathrm{k}>0.05\right)$.

Table 5. Chi-square test result on the relationship between respondents' willingness to pay (WTP) and their acceptance of heritage tourism development in the study area.

\begin{tabular}{|c|c|c|c|c|c|}
\hline & Value $\left(X^{2}\right)$ & df & $\begin{array}{l}\text { Asymp. Sig. } \\
\text { (2-Sided) }\end{array}$ & $\begin{array}{l}\text { Exact Sig. } \\
\text { (2-Sided) }\end{array}$ & $\begin{array}{l}\text { Exact Sig. } \\
\text { (1-Sided) }\end{array}$ \\
\hline $\begin{array}{c}\text { Pearson } \\
\text { Chi-Square }\end{array}$ & $0.365^{\mathrm{a}}$ & 1 & 0.546 & \multirow{6}{*}{0.586} & \multirow{6}{*}{0.377} \\
\hline $\begin{array}{l}\text { Continuity } \\
\text { Correction } b\end{array}$ & 0.103 & 1 & 0.748 & & \\
\hline $\begin{array}{l}\text { Likelihood } \\
\text { Ratio }\end{array}$ & 0.369 & 1 & 0.543 & & \\
\hline $\begin{array}{l}\text { Fisher's } \\
\text { Exact Test } \\
\text { Linear-by- }\end{array}$ & & & & & \\
\hline $\begin{array}{c}\text { Linear } \\
\text { Association }\end{array}$ & 0.364 & 1 & 0.546 & & \\
\hline $\begin{array}{c}N \text { of Valid } \\
\text { Cases } b\end{array}$ & 392 & & & & \\
\hline
\end{tabular}

a. 0 cells $(0.0 \%)$ have an expected count of less than 5 . The minimum expected count is $6.07 .^{\mathrm{b}}$. Computed only for a $2 \times 2$ table. 
In addition, as illustrated in Table 6 and Figure 7, an interesting finding showed that majority of respondents $(96.2 \%, 201$ frequencies) were not willing to pay for heritage conservation but accepted the choice of heritage tourism development in the study area. Besides, the results showed that respondents' acceptance of heritage tourism development in the study area was not influenced by their willingness to pay for the cost of funding for heritage tourism development purposes.

Table 6. Cross-tabulation between respondents' willingness to pay (WTP) for the heritage conservation and their acceptance of Jugra as a heritage tourism site.

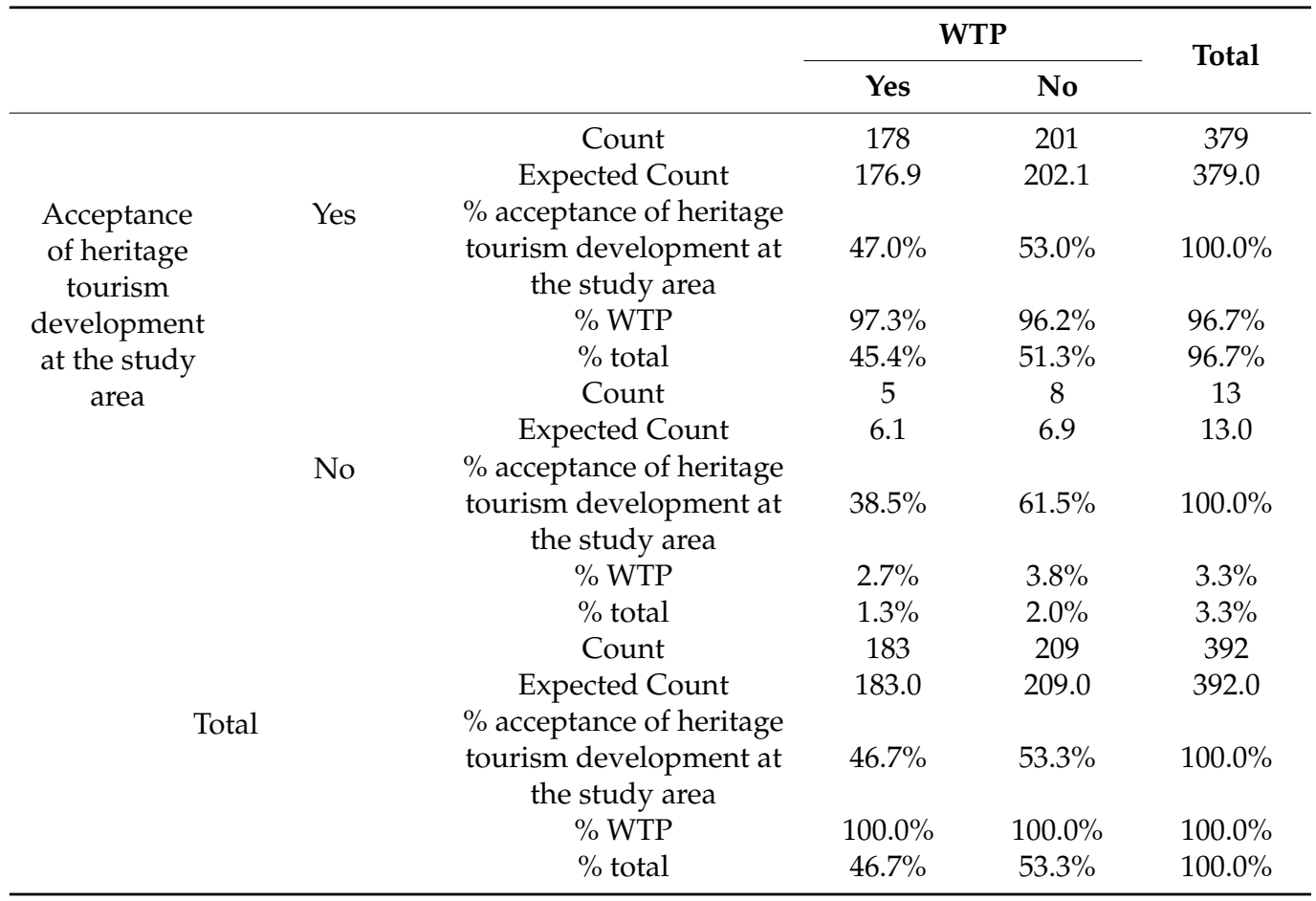

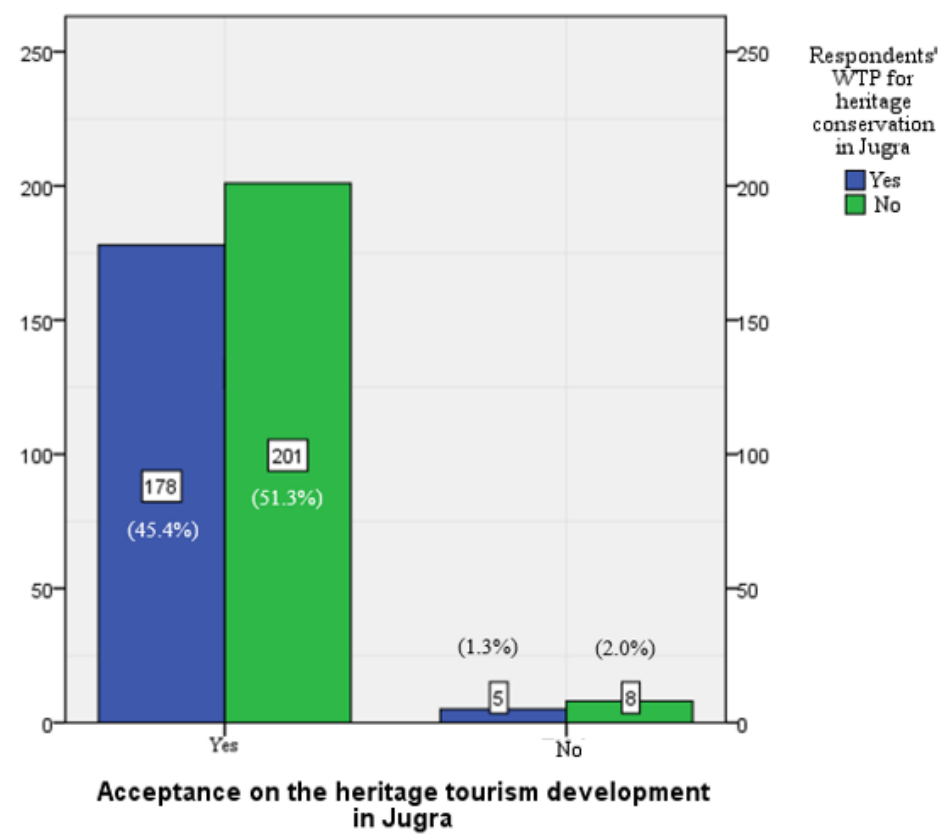

Figure 7. Bar chart of respondents' willingness to pay for heritage conservation and their acceptance of heritage tourism development in the study area. 


\subsection{Inference Analysis-Structural Equation Modelling (SEM)}

3.2.1. Index Category and Parameter (Level of Acceptance) for Each Index

Table 7 indicates the list of indexes that are involved in the structural equation model by their category. Each index has its own parameter based on the level of acceptance to determine the significance value.

Table 7. Index category and parameter or level of acceptance for each index.

\begin{tabular}{|c|c|c|c|}
\hline Category & Index & $\begin{array}{l}\text { Index and } \\
\text { Parameter }\end{array}$ & Notes \\
\hline \multirow{4}{*}{ Absolute fit } & Probability ( $p$-Value) & $p<0.05$ & $\begin{array}{l}\text { Value must be less than } \\
0.05 \text { or } * * *\end{array}$ \\
\hline & Discrepancy Chi Square & Chisq $>0.05$ & $\begin{array}{c}\text { Sensitive to a size sample } \\
\text { over } 200\end{array}$ \\
\hline & $\begin{array}{l}\text { Root Mean Square of } \\
\text { Error Approximation }\end{array}$ & RMSEA $<0.08$ & $\begin{array}{c}\text { Range of value } 0.05 \text { to } 1.0 \\
\text { acceptable }\end{array}$ \\
\hline & Goodness of Fit Index & GFI $>0.90$ & $\mathrm{GFI}=0.95$ is ideal \\
\hline \multirow{4}{*}{ Incremental fit } & Adjusted Goodness of Fit & AGFI $>0.90$ & AGFI $=0.95$ is ideal \\
\hline & Comparative Fit Index & $\mathrm{CFI}>0.90$ & $\mathrm{CFI}=0.95$ is ideal \\
\hline & Tucker-Lewis Index & TLI $>0.90$ & $\mathrm{TLI}=0.95$ is ideal \\
\hline & Normed Fit Index & $\mathrm{NFI}>0.90$ & $\mathrm{NFI}=0.95$ is ideal \\
\hline Parsimonious fit & $\begin{array}{c}\text { Chi square/Degree of } \\
\text { Freedom }\end{array}$ & Chisq/df $<5.0$ & Value must be less than 5.0 \\
\hline
\end{tabular}

3.2.2. Statistical Test for Correlation between the Uniqueness of the Heritage Elements and Respondents' WTP for Heritage Conservation and Tourism Development

Table 8 illustrates the results from the structural equation model in Figure 8. The regression test result shows that the relationship between the uniqueness of the heritage elements and respondents' willingness to pay (WTP) for the cost of funding in heritage tourism development purposes was significant by obtaining a $p$-value (WTP $\leftarrow \mathrm{HU}$ ) of less than 0.05 .

Table 8. Regression weights for the correlation between the uniqueness of heritage elements in the study area and respondents' willingness to pay (WTP) for heritage conservation and tourism development.

\begin{tabular}{|c|c|c|c|c|c|c|}
\hline Statement & Path & Estimate & S.E. & C.R. & $p$ & Result \\
\hline $\begin{array}{l}\text { Sc6i-The remains of the } \\
\text { monuments or old } \\
\text { buildings }\end{array}$ & $\mathrm{Sc} 6 \mathrm{i} \leftarrow \mathrm{HU}$ & 1.000 & & & & \\
\hline Sc6ii-History & $\begin{array}{c}\text { Sc6ii } \leftarrow \\
\text { HU }\end{array}$ & 0.526 & 0.157 & 3.344 & $* * *$ & Significant \\
\hline $\begin{array}{c}\text { Sc6iii-The beauty of } \\
\text { nature }\end{array}$ & $\begin{array}{c}\text { Sc6iii } \leftarrow \\
\text { HU }\end{array}$ & 0.756 & 0.198 & 3.828 & $* * *$ & Significant \\
\hline $\begin{array}{l}\text { Sc9i-Physical features or } \\
\text { landforms } \\
\text { Question: }\end{array}$ & $\mathrm{Sc} 9 \mathrm{i} \leftarrow \mathrm{HU}$ & 1.286 & 0.321 & 4.007 & $* * *$ & Significant \\
\hline $\begin{array}{l}\text { Are you willing to pay for } \\
\text { the funding of heritage } \\
\text { conservation and } \\
\text { protection in Jugra? }\end{array}$ & $\begin{array}{c}\text { WTP } \leftarrow \\
\text { HU }\end{array}$ & 0.496 & 0.175 & 2.833 & 0.005 & Significant \\
\hline \multicolumn{6}{|c|}{$\begin{array}{l}\text { There is a significant statistical correlation between the uniqueness of heritage } \\
\text { elements in Jugra and respondents' willingness to pay for heritage conservation and } \\
\text { tourism development purposes. }\end{array}$} & $\begin{array}{c}p<0.05 \\
\text { Acceptable }\end{array}$ \\
\hline
\end{tabular}




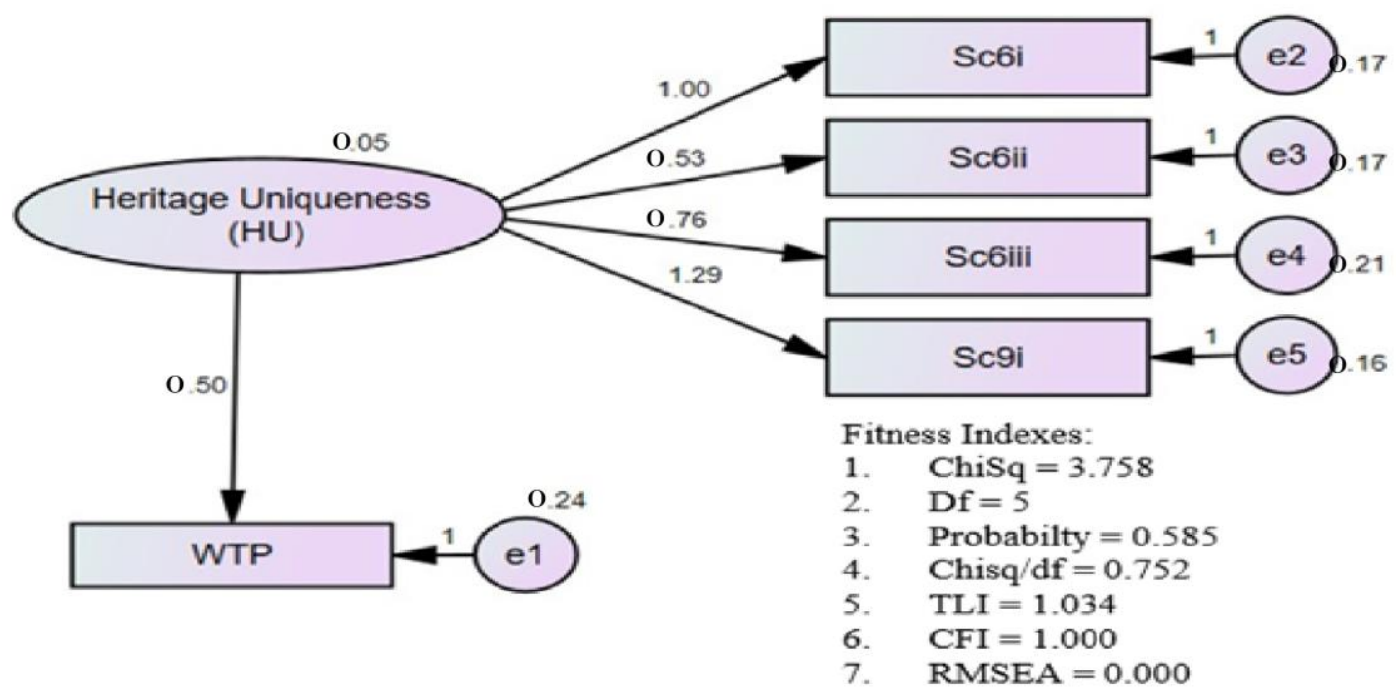

Figure 8. Structural equation model for correlation between the uniqueness of heritage elements in the study area and respondents' willingness to pay (WTP) for heritage conservation and tourism development.

The result showed that the uniqueness of the heritage elements in the study area remained the key factor in encouraging the respondents to contribute to the cost of funding heritage tourism development. Thus, the statement of hypothesis $\left(\mathrm{H}_{1}\right)$ is supported.

3.2.3. Statistical Test for Correlation between the Uniqueness of the Heritage Elements in the Study Area and Respondents' Acceptance of Heritage Tourism Development

Table 9 represents the results from the structural equation model in Figure 9. As depicted in the table, the $p$-value attained (Acceptance $\leftarrow \mathrm{HU}$ ) was less than 0.005 . The result showed that the uniqueness of heritage elements in the study area had a significant relationship with their acceptance of heritage tourism development. The findings revealed that the remains of old building and monuments, the history, and the beauty of nature in the study area were the core factors influencing the respondents in making the decision to protect the heritage area (option value and bequest value-refer to the subtopic of "semiotics" in the study). Based on the findings, the study revealed that the respondents' positive valuation and awareness of the protection of the heritage proved that there is an appreciation for preserving the inherited treasures that reflect their identity (legacy value-refer to subtopic of "semiotics" in the study). These legacies are considered a symbol that replicates the history related to the local people and their surroundings. The finding matched with the use of the semiotics theory in the study, as explained in the previous paragraph. Thus, hypothesis $\mathrm{H}_{2}$ is supported.

3.2.4. Statistical Test on Socioeconomic Factors as a Moderator between Respondents' Dispositions towards Heritage Preservation and Their Acceptance of Tourism Development in the Study Area

Table 10 represents the result of the regression test from the structural equation model in Figure 10, where the $p$-value for the path from respondents' dispositions in preserving heritage to respondents' acceptance of the study area as a heritage tourism site as 0.089 is deemed insignificant. 
Table 9. Regression weights for the correlation between the uniqueness of the heritage elements in the study area and respondents' consent to heritage tourism development.

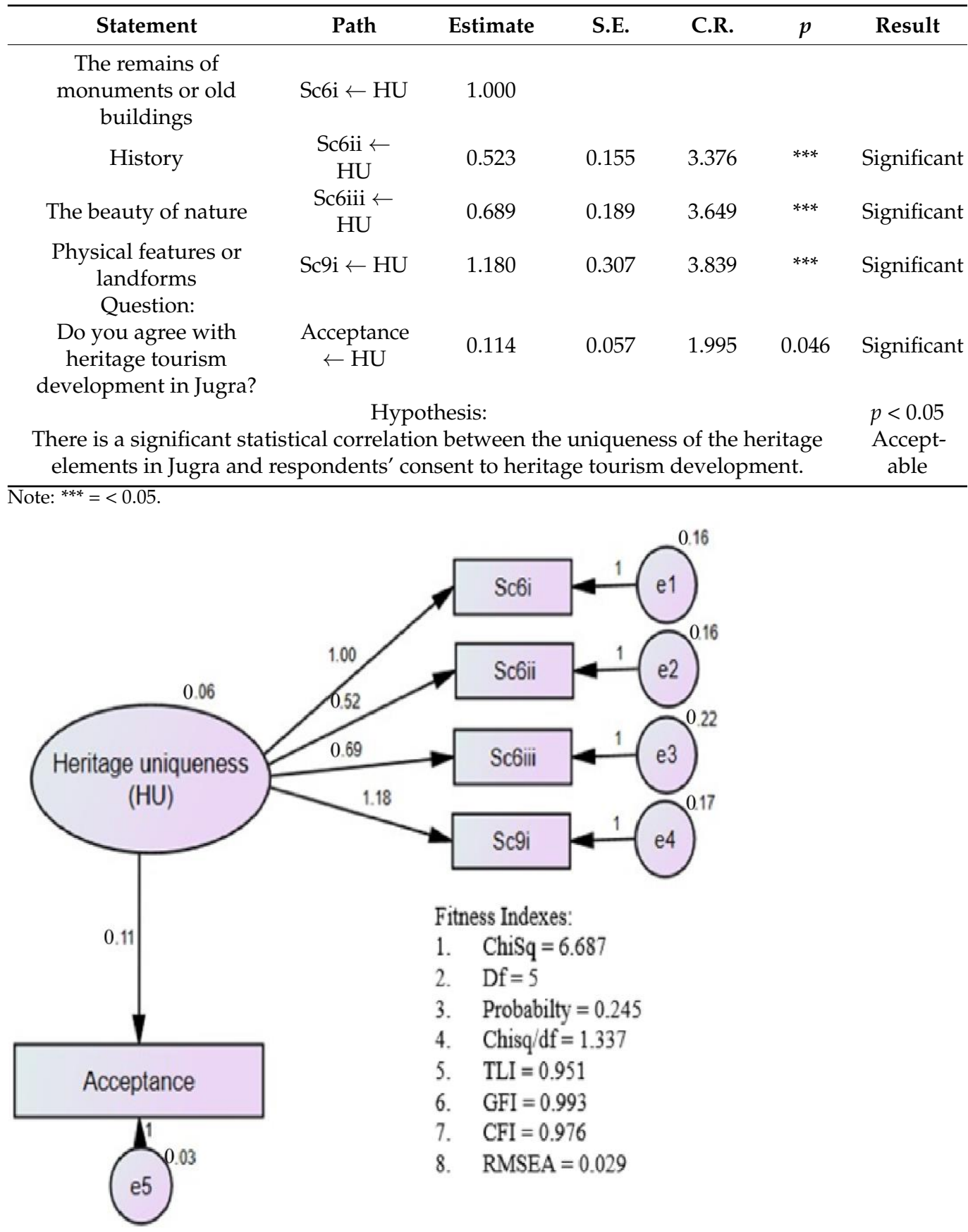

Figure 9. Structural equation model for the correlation between the uniqueness of the heritage elements in the study area and respondents' willingness to pay (WTP) for heritage conservation and tourism development. 
Table 10. Regression weights to test the socioeconomic factors as a moderator between respondents' dispositions towards heritage preservation and their acceptance of tourism development in the study area (unconstraint).

\begin{tabular}{|c|c|c|c|c|c|}
\hline Statement/Path & Estimate & S.E. & C.R. & $p$ & Result \\
\hline $\begin{array}{c}\text { Sb4viii-It is important to protect } \\
\text { the heritage area even though we } \\
\text { have never visited the area } \leftarrow \\
\text { Dispositions }\end{array}$ & 1.000 & & & & \\
\hline $\begin{array}{l}\text { Sb4iv-Cultural and natural } \\
\text { heritage in Jugra are valuable assets } \\
\leftarrow \text { Dispositions }\end{array}$ & 0.989 & 0.070 & 14.110 & $* * *$ & Significant \\
\hline $\begin{array}{l}\text { Sb4i-Jugra historical sites should } \\
\text { be preserved } \leftarrow \text { Dispositions }\end{array}$ & 1.161 & 0.070 & 16.597 & $* * *$ & Significant \\
\hline $\begin{array}{l}\text { Sb4x-Heritage assets can provide } \\
\text { benefit to the economy, especially in } \\
\text { the tourism sector } \leftarrow \text { Dispositions }\end{array}$ & 0.961 & 0.067 & 14.325 & $* * *$ & Significant \\
\hline $\begin{array}{l}\text { Sb4ii-Maintaining the features } \\
\text { and originality of building design is } \\
\text { important } \leftarrow \text { Dispositions }\end{array}$ & 1.120 & 0.065 & 17.230 & $* * *$ & Significant \\
\hline $\begin{array}{c}\text { Respondents' acceptance of Jugra } \\
\text { as a heritage tourism site } \leftarrow \\
\text { Dispositions }\end{array}$ & -0.027 & 0.016 & -1.700 & 0.089 & $\begin{array}{l}\text { Not Sig- } \\
\text { nificant }\end{array}$ \\
\hline Sa6-Education $\leftarrow$ Socioeconomic & 1.000 & & & & \\
\hline Sa7-Occupation $\leftarrow$ Socioeconomic & -1.812 & 0.158 & -11.444 & $* * *$ & Significant \\
\hline Sa8-Income $\leftarrow$ Socioeconomic & 2.568 & 0.223 & 11.512 & $* * *$ & Significant \\
\hline $\begin{array}{c}\text { Respondents' acceptance of Jugra } \\
\text { as a heritage tourism site } \leftarrow \\
\text { Socioeconomic }\end{array}$ & 0.039 & 0.019 & 2.070 & 0.038 & Significant \\
\hline
\end{tabular}

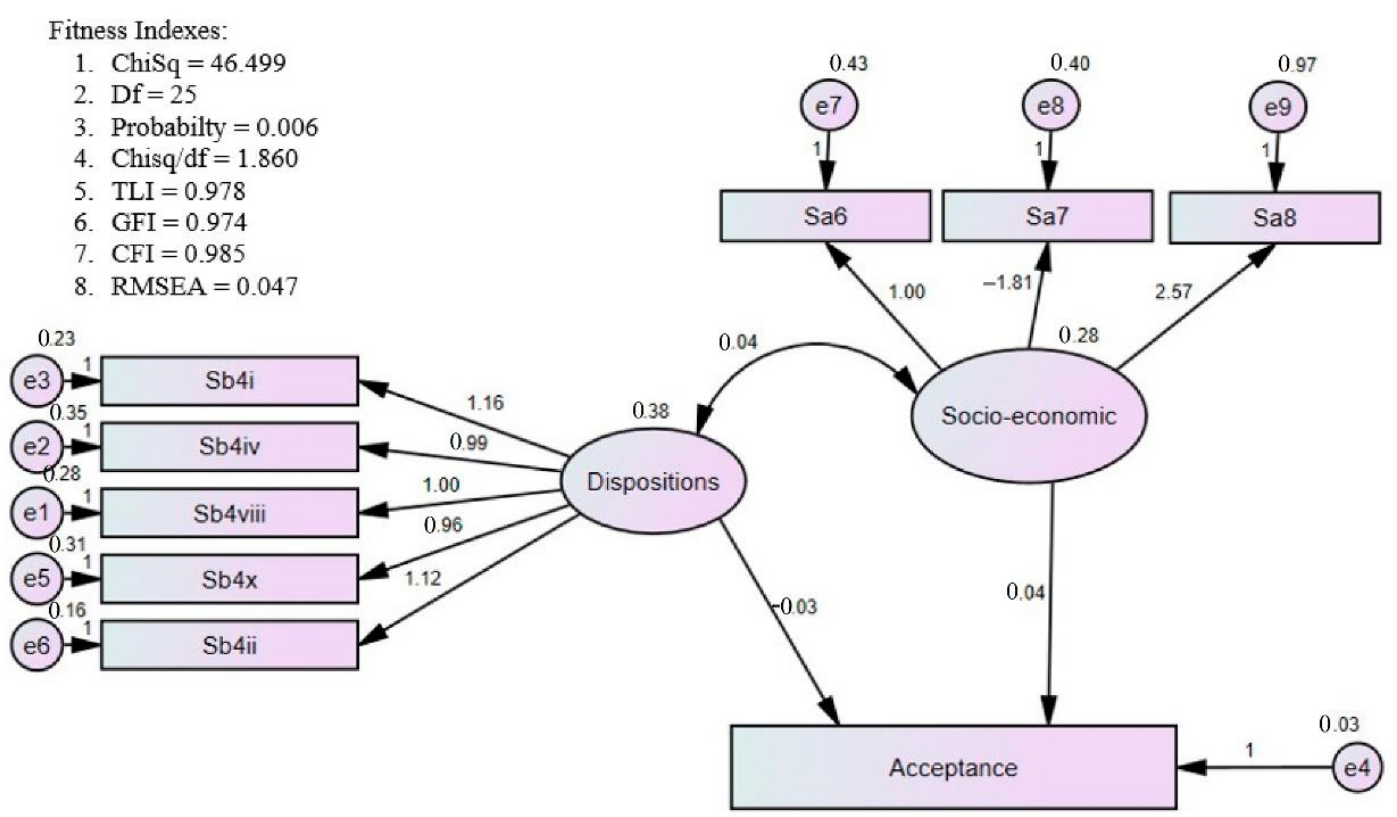

Figure 10. Structural equation model to test socioeconomic factors as a moderator between respondents' dispositions towards heritage preservation and their acceptance of tourism development in the study area (unconstraint).

Table 11 represents the result of the regression test from the structural equation model. The $p$-value for the path from respondents' dispositions towards preserving the heritage to respondents' acceptance of the study area as a heritage tourism site after it had been constrained was 0.044 . This resulted in a change from "not significant" to "significant." 
Table 11. Regression weights to test socioeconomic factors as a moderator between respondents' dispositions towards heritage preservation and their acceptance of tourism development in the study area (constraint).

\begin{tabular}{|c|c|c|c|c|c|}
\hline Statement/Path & Estimate & S.E. & C.R. & $p$ & Result \\
\hline $\begin{array}{l}\text { Sb4viii-It is important to protect the heritage area even } \\
\text { though we have never visited the area } \leftarrow \text { Dispositions }\end{array}$ & 1.000 & & & & \\
\hline $\begin{array}{c}\text { Sb4iv-Cultural and natural heritage in Jugra are } \\
\text { valuable assets } \leftarrow \text { Dispositions }\end{array}$ & 0.989 & 0.070 & 14.126 & $* * *$ & Significant \\
\hline $\begin{array}{c}\text { Sb4i-Jugra's historical sites should be preserved } \leftarrow \\
\text { Dispositions }\end{array}$ & 1.160 & 0.070 & 16.602 & $* * *$ & Significant \\
\hline $\begin{array}{l}\text { Sb } 4 x-\text { - Heritage assets as a benefit to the economy, } \\
\text { especially in the tourism sector } \leftarrow \text { Dispositions }\end{array}$ & 0.961 & 0.067 & 14.329 & $* * *$ & Significant \\
\hline $\begin{array}{l}\text { Sb4ii-Maintaining the features and originality of } \\
\text { building design is important } \leftarrow \text { Dispositions }\end{array}$ & 1.119 & 0.065 & 17.233 & $* * *$ & Significant \\
\hline $\begin{array}{l}\text { Respondents' acceptance of Jugra as a heritage tourism } \\
\text { site } \leftarrow \text { Dispositions }\end{array}$ & -0.032 & 0.016 & -2.009 & 0.044 & Significant \\
\hline Sa6-Education $\leftarrow$ Socioeconomic & 1.000 & & & & \\
\hline Sa7-Occupation $\leftarrow$ Socioeconomic & -18.993 & 4.184 & -4.539 & $* * *$ & Significant \\
\hline Sa8-Income $\leftarrow$ Socioeconomic & 32.701 & 8.226 & 3.975 & $* * *$ & Significant \\
\hline $\begin{array}{c}\text { Respondents' acceptance of Jugra as a heritage tourism } \\
\text { site } \leftarrow \text { Socioeconomic }\end{array}$ & 1.000 & & & & \\
\hline
\end{tabular}

Note: ${ }^{* * *}=<0.05$.

The result of the fitness indexes in Figure 11 displays the constraint model of the structural equation, where the parameter value of the path from socioeconomic to acceptance is converted to 1 (in the red dropline), as indicated.

Fitness Indexes:

1. $\mathrm{ChiSq}=178.979$

2. $\mathrm{Df}=26$

3. Probabilty $=0.000$

4. Chisq $/ \mathrm{df}=6.884$

5. $\mathrm{TLI}=0.851$

6. $\mathrm{GFI}=0.916$

7. $\mathrm{CFI}=0.893$

8. $\mathrm{RMSEA}=0.123$

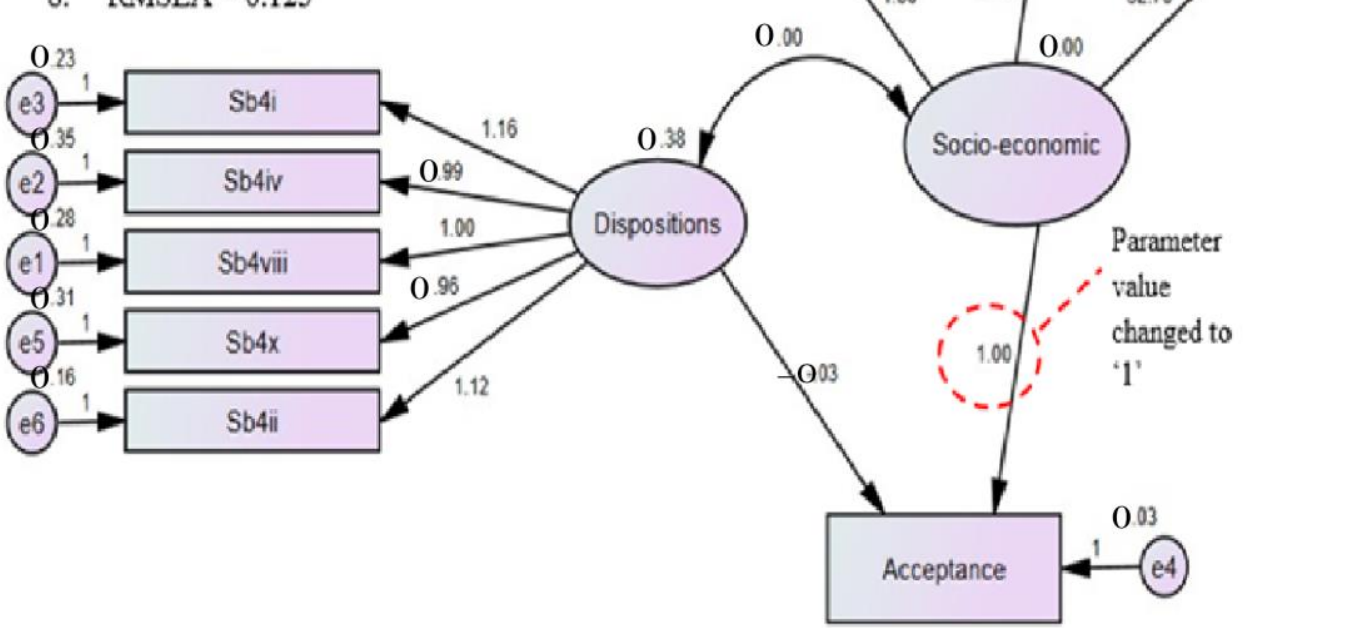

Figure 11. Structural equation model to test socioeconomic factors as a moderator between respondents' dispositions towards heritage preservation and their acceptance of tourism development in the study area (unconstraint).

As indicated in Table 12, the difference in chi-square values in between the constraint and unconstraint model was 132.48, with a degree of freedom (DF) of 1. According to Awang [71], the correlation between two variables is significant when the difference of 
the chi-square value is more than 3.84 by a difference of DF equal to 1 . Besides that, the $p$-value between the path of respondents' acceptance of Jugra as a heritage tourism site and respondents' disposition towards preserving heritage changed from 0.089 (unconstraint) to 0.044 (constraint). This resulted in the equation for constraint model being significant $(<0.05)$. Thus, the findings showed that the socioeconomic factors of education, professions, and monthly gross income influenced respondents' dispositions towards preserving the heritage and that they agreed with heritage tourism development in Jugra. The hypothesis $\left(\mathrm{H}_{3}\right)$ is acceptable. This study revealed that educating children about the valuable of heritage preservation is very important (bequest value-refer to the subtopic of "semiotics" in the study). There is a need to educate the young in order to heighten awareness of heritage preservation and conservation so that it can be sustained for future generations and the ecosystem's well-being. Figure 12 illustrates the combination of all the structural equation models that were involved in the study. Concisely, all the fitness indexes reached the standard value, which demonstrated their significant correlations.

Table 12. Result of the moderation test on socioeconomic factors as a moderator between respondents' dispositions towards preserving heritage and their acceptance of tourism development in the study area.

\begin{tabular}{|c|c|c|c|c|c|}
\hline Index & $\begin{array}{l}\text { Unconstraint } \\
\text { Model }\end{array}$ & $\begin{array}{l}\text { Constraint } \\
\text { Model }\end{array}$ & $\begin{array}{l}\text { Chi-Square } \\
\text { Difference }\end{array}$ & $\begin{array}{l}\text { Moderation } \\
\text { Outcome }\end{array}$ & Hypothesis Result \\
\hline Chi-Square & 46.499 & 178.979 & 132.48 & Significant & \\
\hline DF & 25 & 26 & & & \\
\hline GFI & 0.974 & 0.916 & & & \\
\hline AGFI & 0.954 & 0.855 & & & \\
\hline CFI & 0.985 & 0.893 & & & \\
\hline RMSEA & 0.047 & 0.123 & & & \\
\hline $\begin{array}{c}\text { Chisq/df } \\
p \text { value of }\end{array}$ & 1.860 & 6.884 & & & \\
\hline $\begin{array}{l}\text { Respondents' acceptance of Jugra } \\
\text { as a heritage tourism site } \leftarrow \\
\text { Respondents' dispositions towards } \\
\text { preserving heritage }\end{array}$ & 0.089 & 0.044 & & & $<0.05$ Significant \\
\hline \multicolumn{5}{|c|}{$\begin{array}{l}\text { Hypothesis: } \\
\begin{array}{l}\text { Socioeconomic factors act as a moderator between respondents' dispositions towards heritage preservation } \\
\text { and their acceptance of tourism development in the study area. }\end{array}\end{array}$} & $\begin{array}{l}\text { Chi-square } \\
\text { difference }>3.84 \\
\text { Acceptable }\end{array}$ \\
\hline
\end{tabular}

Note: The moderation test result is significant when the difference in chi-square value between the constraint and unconstraint model is not less than 3.84 (Awang, 2014, p. 164).

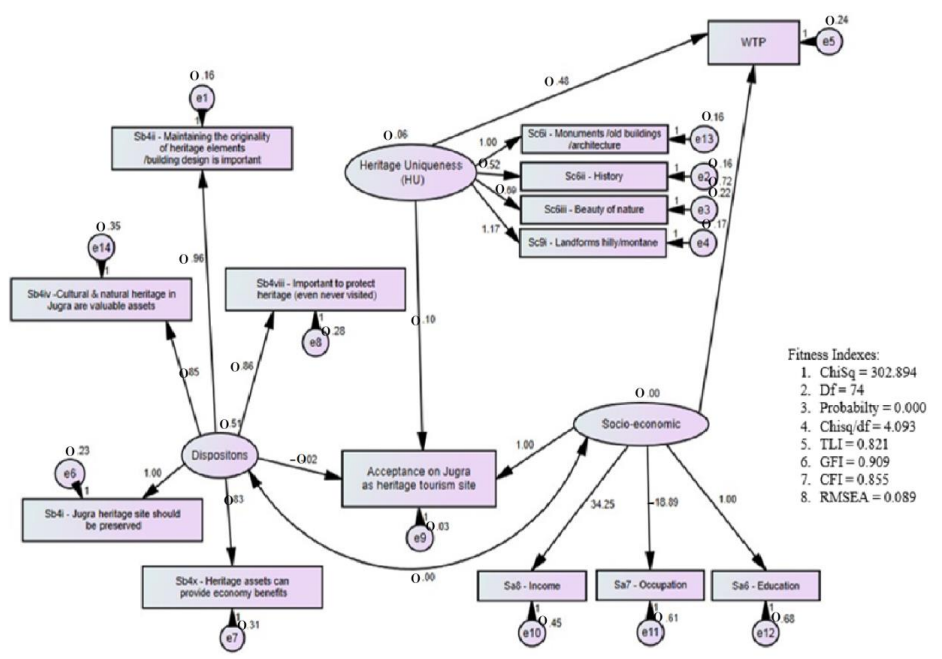

Figure 12. Combination of all structural equation models for all variables involved in the study. 


\section{Conclusions}

Overall, the study found that the majority of the 392 total respondents support cultural heritage and natural heritage protection for tourism development in Jugra. Based on the survey data, there is an interesting finding showed that the majority of respondents were not willing to pay for the heritage conservation but accepted the choice of heritage tourism development in the study area. In addition, the results showed that respondents' acceptance of heritage tourism development in the study area was not influenced by their willingness to pay for the cost of funding for heritage tourism development purposes. However, the correlation test through cross-tabulation analysis proved that the respondents' acceptance of heritage tourism development in the study area did not affect their willingness to pay for heritage tourism development efforts. An outstanding result showed that there was an intrinsic value among respondents who were aware of the importance of the preservation and conservation of heritage elements, despite having never seen the treasures. Nonetheless, they still wanted to protect it for the benefit of others and future generations. The study also supports the hypothesis statements of the cultural and natural heritage elements' uniqueness in Jugra, which had an influence on respondents' acceptance of heritage tourism development in the area and their willingness to contribute to the funding costs (legacy value, option value). The statistical result was well suited to the findings that discovered that the main factor in respondents' willingness to pay for heritage protection was in the attractiveness and uniqueness of the heritage elements in the area. The findings also revealed that the remains of old buildings and monuments, the history, and the beauty of nature in the study area were the core factors in influencing the respondents to make the decision to protect the heritage area. Based on the findings, the study revealed that respondents' positive valuation and awareness of the protection of heritage proved that there is an appreciation for preserving the inherited treasures that reflect their identity or legacy value. These legacies are considered a symbol that replicates the history of the local people and their surroundings. The findings matched with the use of the semiotics theory in the study. The socioeconomic factors of education, professions, and monthly gross income influenced respondents' disposition towards preserving the heritage and supported heritage tourism development in Jugra. This study revealed that educating children about the value of heritage preservation is very important (bequest value-refer to the subtopic of "semiotics" in the study). There is a need to educate the young in order to heighten awareness of heritage preservation and conservation so that it can be sustained for future generation and the ecosystem's well-being.

Rationally, this study encouraged the involvement of the local community, who should be an integral part of the stakeholders in the decision-making throughout the planning and management processes in tourism development. The locals' involvement is important not only financially, but also in terms of support and promotion. Their awareness of heritage protection significance is important for educating younger generations' dispositions towards preserving heritage assets. The limitation of this study is mainly the focus on the reflection of the local community and their willingness to pay for heritage protection of historic buildings, monuments, and archaeological sites in Jugra, Selangor, Malaysia. A suggestion for further studies in Jugra can be to focus on heritagization, which refers to the transformation of objects, places, and practices into cultural heritage as value attached to them, essentially describing heritage as a process. Another fundamental concept of validating heritage within conservation practice is based on aspects of heritage values, authenticity, and integrity.

Author Contributions: Conceptualization, Z.B.R. and Z.R.; methodology, Z.B.R. and Z.R.; software, Z.B.R.; validation, Z.R.; formal analysis, Z.B.R., Z.R. and M.R.R.; investigation, Z.B.R., Z.R. and M.R.R.; resources, Z.R.; data curation, Z.B.R. and Z.R.; writing-original draft preparation, Z.B.R. and Z.R.; writing-review and editing, Z.B.R., Z.R., M.R.R., M.R.M.A., M.R.I., R.A.I. and N.M.N.; visualization, Z.B.R. and Z.R.; supervision, Z.R.; project administration, Z.R.; funding acquisition, Z.R. All authors have read and agreed to the published version of the manuscript. 
Funding: This research was funded by Universiti Kebangsaan Malaysia through a research grant.

Institutional Review Board Statement: Not applicable.

Informed Consent Statement: Not applicable.

Data Availability Statement: The data presented in this study are available within this article.

Acknowledgments: The authors are very thankful to Universiti Kebangsaan Malaysia (UKM) for providing the facilities to conduct the research.

Conflicts of Interest: The authors declare no conflict of interest.

\section{References}

1. The United Nations Educational, Scientific and Cultural Organization. Operational Guidelines for the Implementation of the World Heritage Convention. Intergovernmental Committee for the Protection of the World Cultural and Natural Heritage, World Heritage Centre. 2012. Available online: https:/ / whc.unesco.org/en/guidelines/ (accessed on 18 October 2018).

2. Zyl, C.J.V. The Role of Tourism in the Conservation of Cultural Heritage with Particular Relevance for South Africa; University of Stellenbosch: Stellenbosch, South Africa, 2005.

3. Maneenetr, T. Khmer Temples of Northeast Thailand: A Proposed Plan for Tourism Development. In Proceedings of the 16th ICOMOS General Assembly and International Symposium: Finding the Spirit of Place between the Tangible and the Intangible, Quebec, QC, Canada, 29 Septenmber-4 October 2008; pp. 1-10.

4. Khalil, S.; Kakar, M.K. Waliullah Role of tourism in economic growth: Empirical evidence from Pakistan economy. Pak. Dev. Rev. 2007, 46, 985-995. [CrossRef]

5. Katircioglu, S.T. Revisiting the tourism-led-growth hypothesis for Turkey using the bounds test and Johansen approach for cointegration. Tour. Manag. 2009, 30, 17-20. [CrossRef]

6. Kadir, N.; Karim, M.Z.A. Turizam i ekonomski rast u maleziji: Dokaziiz tourističkih dolazaka iz ASEAN-5 zemalja. Ekon. Istraz. 2012, 25, 1089-1100. [CrossRef]

7. Adnan Hye, Q.M.; Ali Khan, R.E. Tourism-Led Growth Hypothesis: A Case Study of Pakistan. Asia Pac. J. Tour. Res. 2013, 18, 303-313. [CrossRef]

8. Khan, A.; Bibi, S.; Lorenzo, A.; Lyu, J.; Babar, Z.U. Tourism and development in developing economies: A policy implication perspective. Sustainability 2020, 12, 1618. [CrossRef]

9. Ali, S.S.S.; Razman, M.R.; Awang, A. The nexus of population, GDP growth, electricity generation, electricity consumption and carbon emissions output in Malaysia. Int. J. Energy Econ. Policy 2020, 10, 84-89. [CrossRef]

10. Ali, S.S.S.; Razman, M.R.; Awang, A.; Asyraf, M.R.M.; Ishak, M.R.; Ilyas, R.A.; Lawrence, R.J. Critical Determinants of Household Electricity Consumption in a Rapidly Growing City. Sustainability 2021, 13, 4441. [CrossRef]

11. Indorf, H. ASEAN: Problems and Prospects; ISEAS Publishing: Singapore, 1975.

12. Lim, C.K.; Tan, K.L.; Zaidan, A.A.; Zaidan, B.B. A proposed methodology of bringing past life in digital cultural heritage through crowd simulation: A case study in George Town, Malaysia. Multimed. Tools Appl. 2020, 79, 3387-3423. [CrossRef]

13. Lim, C.K.; Ahmed, M.F.; Mokhtar, M.B.; Tan, K.L.; Idris, M.Z.; Chan, Y.C. Understanding intangible culture heritage preservation via analyzing inhabitants' garments of early 19th century in weld quay, Malaysia. Sustainability 2021, 13, 5393. [CrossRef]

14. Farahani, B.M.; Abooali, G.; Mohamed, B. George Town World Heritage Site: What We Have and What We Sell? Asian Cult. Hist. 2012, 4, 81-90. [CrossRef]

15. Liu, Y. Application of Jiangxi intangible cultural heritage in modern fashion design. In Proceedings of the 2017 3rd International Conference on Economics, Social Science, Arts, Education and Management Engineering (ESSAEME 2017), Huhhot, China, 29-30 July 2017; Volume 119, pp. 688-691.

16. Daeng Jamal, D.H.; Ramli, Z. Pemuliharaan beberapa bangunan bersejarah di Kelantan: Tinjauan ke atas penglibatan komuniti setempat dalam suai guna semula Conservation of several historic buildings in Kelantan: A survey on involvements of the local community in adaptive reuse. Geogr. J. Soc. Sp. 2021, 2, 461-474.

17. Omar Din, M.A.; Zakaria, Z. Pelancongan Budaya di Malaysia: Membina Konsepnya. J. Melayu. 2011, 6, 1-11.

18. Ali, S.S.S.; Razman, M.R.; Awang, A. The estimation and relationship of domestic electricity consumption and appliances ownership in Malaysia's intermediate city. Int. J. Energy Econ. Policy 2020, 10, 116-122. [CrossRef]

19. Zainuddin, S.; Mascunra Amir, A.; Kibi, Y.R.; Khairil, M.; Zarina Syed Zakaria, S.; Rizal Razman, M. Social engineering model of natural resources management of Palu City. J. Eng. Appl. Sci. 2019, 14, 275-279. [CrossRef]

20. Ramli, Z. Archaelogy, culture and history: Concept and potential as a product of heritage tourism in Malaysia and Indonesia. In Proceedings of the Prosiding Seminar Antarabangsa Arkeologi, Sejarah, Budaya dan Bahasa di Alam Melayu Nusantara (ASBAM) ke-5, Makassar, Indonesia, 26-27 July 2016; pp. 60-91.

21. Woynar, M. Reconsidering the Definition of Mexican Archaeological Heritage. Conserv. Manag. Archaeol. Sites 2007, 9, 38-48. [CrossRef]

22. Ramsey, D.; Everitt, J. If you dig it, they will come! Archaeology heritage sites and tourism development in Belize, Central America. Tour. Manag. 2008, 29, 909-916. [CrossRef] 
23. Al-Busaidi, Y.S.A. Public Interpretation of Archaeological Heritage and Achaeotourism in the Sultanate of Oman; Cardiff Metropolitan University: Wales, UK, 2008.

24. Pacifico, D.; Vogel, M. Archaeological sites, modern communities, and tourism. Ann. Tour. Res. 2012, 39, 1588-1611. [CrossRef]

25. Ross, D.; Saxena, G.; Correia, F.; Deutz, P. Archaeological tourism: A creative approach. Ann. Tour. Res. 2017, 67, 37-47. [CrossRef]

26. Shrivastava, S. Archaeotourism: An Approach to Heritage Conservation and Area Development. Glob. J. Eng. Sci. Soc. Sci. Stud. 2016, 1, 31-42.

27. Abdurahman, A.Z.A.; Ali, J.K.; Khedif, L.Y.B.; Bohari, Z.; Ahmad, J.A.; Kibat, S.A. Ecotourism Product Attributes and Tourist Attractions: UiTM Undergraduate Studies. Procedia. Soc. Behav. Sci. 2016, 224, 360-367. [CrossRef]

28. Salman, A.; Mohamad, D. e-Review of Tourism Research (eRTR). e Rev. Tour. Res. 2020, 18, 215-233.

29. Choy, E.A. Pembangunan pelancongan lestari di Melaka: Perspektif pelancong. Geogr. J. Soc. Sp. 2013, 9, 12-23.

30. Navrud, S.; Ready, R.C. Valuing Cultural Heritage: Appliying Environmental Valuation Techniques to Historic Building, Monuments and Artefacts; Edward Elgar Publishing Ltd.: Cheltenham, UK, 2002.

31. Samdin, Z. Willingness to Pay in Taman Negara: A Contingent Valuation Method. Int. J. Econ. Manag. 2008, 2, 81-94.

32. Ahmad, S.A. Visitor's Willingness to Pay for an Entrance Fee: A Case Study of Marine Parks in Malaysia; University of Glasgow: Glasgow, Scotland, 2009.

33. Throsby, D.; Zednik, A.; Araña, J.E. Public preferences for heritage conservation strategies: A choice modelling approach. J. Cult. Econ. 2021. [CrossRef]

34. Castro-Calviño, L.; Rodríguez-Medina, J.; Gómez-Carrasco, C.J.; López-Facal, R. Patrimonializarte: A heritage education program based on new technologies and local heritage. Educ. Sci. 2020, 10, 176. [CrossRef]

35. Gizzi, F.T.; Biscione, M.; Danese, M.; Maggio, A.; Pecci, A.; Sileo, M.; Potenza, M.R.; Masini, N.; Ruggeri, A.; Sileo, A.; et al. Students Meet Cultural Heritage: An Experience within the Framework of the Italian School-Work Alternation (SWA)—From Outcomes to Outlooks. Heritage 2019, 2, 1986-2016. [CrossRef]

36. DeSilvey, C.; Harrison, R. Anticipating loss: Rethinking endangerment in heritage futures. Int. J. Herit. Stud. 2020, 26, 1-7. [CrossRef]

37. Smith, L. Editorial: A critical Heritage Studies? Int. J. Herit. Stud. 2012, 18, 533-540. [CrossRef]

38. Matsuda, A.; Mengoni, L.E. Introduction: Reconsidering Cultural Heritage in East. Asia; Ubiquity Press: London, UK, 2016.

39. Muganda, M.; Sirima, A.; Ezra, P.M. The role of local communities in tourism development: Grassroots perspectives from Tanzania. J. Hum. Ecol. 2013, 41, 53-66. [CrossRef]

40. Asyraf, M.R.M.; Rafidah, M.; Ishak, M.R.; Sapuan, S.M.; Yidris, N.; Ilyas, R.A.; Razman, M.R. Integration of TRIZ, Morphological Chart and ANP method for development of FRP composite portable fire extinguisher. Polym. Compos. 2020, 41, $2917-2932$. [CrossRef]

41. Asyraf, M.R.M.; Ishak, M.R.; Sapuan, S.M.; Yidris, N. Conceptual design of creep testing rig for full-scale cross arm using TRIZ-Morphological chart-analytic network process technique. J. Mater. Res. Technol. 2019, 8, 5647-5658. [CrossRef]

42. Asyraf, M.R.M.; Ishak, M.R.; Sapuan, S.M.; Yidris, N. Conceptual design of multi-operation outdoor flexural creep test rig using hybrid concurrent engineering approach. J. Mater. Res. Technol. 2020, 9, 2357-2368. [CrossRef]

43. Azman, M.A.; Asyraf, M.R.M.; Khalina, A.; Petrů, M.; Ruzaidi, C.M.; Sapuan, S.M.; Wan Nik, W.B.; Ishak, M.R.; Ilyas, R.A.; Suriani, M.J. Natural Fiber Reinforced Composite Material for Product Design: A Short Review. Polymers 2021, 13, 1917. [CrossRef] [PubMed]

44. Mohd Ariffin, N.F. Willingness to Pay Value of Cultural Heritage and Its Management for Sustainable Conservation of Georgetown, World Heritage Site; Universiti Malaya: Kuala Lumpur, Malaysia, 2015.

45. Aref, F. Sense of community and participation for tourism development. Life Sci. J. 2011, 8, $20-25$.

46. Dávid, L. Tourism ecology: Towards the responsible, sustainable tourism future. Worldw. Hosp. Tour. Themes 2011, 3, 210-216. [CrossRef]

47. Mohd Din, N.A. Return Interview Questions in Written-Answer. Managing Director of Tourism Selangor Sdn; Bhd. (TSSB): Perai, Malaysia, 2016.

48. Ahmad, M.Z.; Ibrahim, J.A.; Mohd Salleh, H. Membangunkan Kedah sebagai destinasi pelancongan warisan: Penerapan konsep pembangunan pelancongan lestari. In Proceedings of the Prosiding Persidangan Kebangsaan Ekonomi Malaysia PERKEM ke-3, Port Dickson, Malaysia, 20-22 August 2008; Volume 1, pp. 401-413.

49. Razman, M.R.; Jahi, J.M.; Mokhtar, M.B.; Arifin, K.; Ramli, Z.; Aiyub, K.; Zakaria, S.Z.S.; Awang, A. The Law of Tort Focusing on Negligence Towards Environmental Sustainability in Malaysia within the Scope of Interest Approach. Res. J. Appl. Sci. 2013, 8, 398-403.

50. Wang, X.; Ren, H.; Wang, P.; Yang, R.; Luo, L.; Cheng, F. A Preliminary Study on Target 11.4 for UN Sustainable Development Goals. Int. J. Geoheritage Park. 2018, 6, 18-24. [CrossRef]

51. Skrede, J.; Hølleland, H. Uses of Heritage and beyond: Heritage Studies viewed through the lens of Critical Discourse Analysis and Critical Realism. J. Soc. Archaeol. 2018, 18, 77-96. [CrossRef]

52. Bakri, A.F.; Yusuf, N.A.; Jaini, N. Managing Heritage Assets: Issues, Challenges and the Future of Historic Bukit Jugra, Selangor. Procedia Soc. Behav. Sci. 2012, 68, 341-352. [CrossRef]

53. Aman, R.; Shahidi, A.H.; Rusydiah, A.S.; Fatin Hakimah, M.F.; Deela, S.M.; Suhailah, R.; Noraniza, A.B.; Nazihah Najw, O.; Mumad, C. River Basin Dialect: Internal Reconstruction Consonant Ancient Of Jugra Dialect. Dialectologia 2021, 26, $27-44$. 
54. Winstedt, R.O. A History of Selangor. J. Malay. Branch R. Asiat. Soc. 1934, 12, 1-34.

55. Gullick, J. The Kuala Langat Piracy Trial. J. Malay. Branch R. Asiat. Soc. 1996, 69, 101-114.

56. Lee, N.I.; Afiqah, F.; Shukri, S.M. The Hybrid Moorish Style Characteristics Malaysia: Istana Bandar Jugra. Malaysia Archit. J. 2020, 2, 24-29.

57. Adil, B. Perjuangan Orang Melayu Menentang Penjajahan Abad 15-19; Dewan Bahasa dan Pustaka: Kuala Lumpur, Malaysia, 1983.

58. Mohd Bisri, N.H. Peranan Kesultanan Melayu-Bugis Terhadap Perkembangan Islam di Selangor: Suatu Kajian Sejarah; Universiti Malaya: Kuala Lumpur, Malaysia, 2003.

59. Roslan, Z.; Ramli, Z.; Shin, C.; Choy, E.A.; Razman, M.R. Local community perception on the importance of cultural-natural heritage protection and conservation: Case study in Jugra, Kuala Langat, Selangor, Malaysia. J. Food Agric. Environ. 2017, 15, 107-110.

60. Roslan, Z.; Ramli, Z.; Abdullah, M.S.Y.; Choy, E.A.; Razman, M.R. Community valuation through their willingness to pay for heritage tourism and sustainable development in Jugra, Selangor, Malaysia. J. Food Agric. Environ. 2017, 15, 116-120.

61. Ong, A. Spirits of Resistance and Capitalist Discipline, 2nd ed.; State University of New York Press: New York, NY, USA, 2010.

62. Chandler, D. Semiotics: The Basics; Routledge: London, UK, 2002.

63. Maccannell, D. The Tourist: A New Theory of the Leisure Class; Schocken Books: New York, NY, USA, 1976.

64. Ribeiro, N.F. Tourism representation and semiotics-direction for future research. Cogitur. J. Tour. Stud. 2009, 2, 7-14.

65. Pennington, J.W.; Thomsen, R.C. A semiotic model of destination representations applied to cultural and heritage tourism marketing. Scand. J. Hosp. Tour. 2010, 10, 33-53. [CrossRef]

66. Culler, J. The Semiotics of Tourism; University of Oklahoma: Norman, OK, USA, 1990.

67. Abdul, K.A.A.; Lee, M.H. Penilaian kontingen ke atas pemuliharaan dan pengekalan Taman Budaya Serawak. In Proceedings of the Prosiding Persidangan Kebangsaan Ekonomi Malaysia PERKEM ke-4, Bangi, Selangor, 2-4 June 2009; pp. 577-593.

68. Bornman, E. Questionnaire surveys in media research. J. Media Stud. 2009, 10, 421-450.

69. Seok, C.B.; Bullare, F.; Mutang, J.A. SPSS Prinsip Dan Analisis Data Dalam Sains Tingkah Laku; Penerbit Universiti Malaysia Sabah: Kota Kinabalu, Malaysia, 2016.

70. Garczynski, J. Chi-Square Test in SPSS (PASW). Available online: https://libguides.library.kent.edu/spss/chisquare (accessed on 16 September 2018).

71. Awang, Z. A Handbook on SEM for Academician and Practitioners; MPWS Rich Resources: Selangor, Malaysia, 2014. 